\title{
Learned Servants: Dutch Ministers, Their Books and the Struggle for a Reformed Republic in the Dutch Golden Age
}

\author{
Forrest $C$. Strickland
}

Reformed ministers played a pivotal role in the seventeenth-century Dutch Republic. As representatives of the public church, they took on a civic role helping to bind fragile communities together in shared belief and practice. ${ }^{1} \mathrm{~A}$ minister preached multiple times a week, and, when possible, attended to the catechising of members and liefhebbers, and visited and comforted the sick and dying. Occasionally, he wrote books to edify believers even when he could not be physically present. Ministers helped shape their congregation's understanding of God, creation, and his expectations for their lives. Through these various forms, they 'supplied all the key terms necessary to understand existence in this world and the next'. ${ }^{2}$ When executing his task faithfully, the minister mediated between his congregation and the cares of the ordinary world. From the pulpit to the deathbed, the ideal minister tirelessly encouraged and exhorted those in their flocks to pursue godliness.

While the public role of ministers is unavoidable in contemporary histories of the seventeenth-century Dutch Republic, little attention has been given to the books they consulted to fulfil their pastoral and public duties. ${ }^{3}$ This is remarkable, because ministers were the largest group of academically trained

1 On the role of the Church and state formation, see Philip S. Gorski, The Disciplinary Revolution: Calvinism and the Rise of the State in Early Modern Europe (Chicago: University of Chicago Press, 2003); Marc Raeff, The Well-Ordered Police State: Social and Institutional Change through Law in the Germanies and Russia, 1600-1800 (New Haven:Yale University Press, 1983); Ronnie Po-Chia Hsia, Social Discipline in the Reformation (Cambridge: Cambridge University Press, 1991); Heinz Schilling, Aufbruch und Krise, Deutschland 1517-1648 (Berlin: Siedler, 1988).

2 Harry S. Stout, The New England Soul: Preaching and Religious Culture in Colonial New England (Oxford: Oxford University Press, 1986), p. 3.

3 For example, Jonathan Israel, The Dutch Republic: Its Rise, Greatness, and Fall, 1477-1806 (Oxford: Clarendon Press, 1995); A. Th. van Deursen, De last van veel geluk. De geschiedenis van Nederland 1555-1702 (Amsterdam: Bert Bakker, 2006); A. Th. van Deursen, 'De Dominee', in H.M. Beliën etc. (eds.), Gestalen van de Gouden Eeuw: Een Hollands groepsportret (Amsterdam: Bert Bakker, 1995), pp. 131-155.

(C) FORREST C. STRICKLAND, $2021 \mid$ DOI:10.1163/9789004448896_020

This is an open access chapter distributed under the terms of the CC BY-NC-ND 4to license 
professionals. ${ }^{4}$ The minister's public role, moreover, ensured that his reading had a much greater impact on society than that of doctors or lawyers, who also valued reading. Ordinary citizens would have had far more personal contact with a minister than with any other university trained intellectual. Educated ministers were dispersed from the urban elite of Amsterdam, Leiden and Rotterdam to the smallest in-land villages of Overijssel or the sandy outposts of Zeeland, and one of the purposes of their libraries was to spread knowledge. Ministers regularly stepped into the public sphere to help bring about a more Reformed society. In their sermons and writings, they investigated the topics that most affected their congregants' lives - economics, law, military theory and history, science and medicine, or knowledge of distant lands - and offered a Reformed synthesis of such knowledge. Their libraries underpinned their efforts to bring about social and theological change, not least through printed publications. Persuading an often lethargic nation required untiring action, and print was a necessary and indeed powerful tool to help bring this about.

This essay seeks to reconstruct the all-important reading of ministers. To do so, it analyses a selection of auction catalogues of ministers' libraries. Throughout the seventeenth century, at least 457 ministerial book collections were auctioned, of which 261 printed catalogues survive. ${ }^{5}$ These catalogues are valuable sources to help understand the intellectual background and inclinations of Dutch ministers and theologians during the seventeenth century, and to gauge how the texts they had acquired were used to affect everyday life. For this essay, I have transcribed and analysed fifty-five Dutch ministerial book collections with a total of 92,183 items. They show that ministers were avid readers on topics of immediate public importance - economics, medicine, astronomy and others - and sought to bring that knowledge to bear on the lives of their neighbours.

\section{Men of Letters}

In 1638 , the Zeeland minister Godefridus Udemans published ' $t$ Geestelyck roer van 't coopmans schip [The Spiritual Rudder of the Merchant's Ship]. ${ }^{6}$

4 On the numbers of ministers in the Dutch Republic, see F.A. van Lieburg, Profeten en hun vaderland: De geografische herkomst van de gereformeerde predikanten in Nederland van 1572 tot 1816 (Zoetermeer: Boekencentrum, 1996).

5 The remaining 196 auctions are inferred from other surviving records: advertisements in newspapers for the auction, magistrates' books that list civil decisions (including when auctions were approved) and similar sources.

6 Godefridus Udemans, 't Geestelyck roervan 't coopmans schip (Dordrecht [Gouda]: Boels [van der Hoeve], 1638) USTC 1019892. 
A moderately popular ethical handbook on the Christian method of seafaring, it would go through three editions by 1655 . The Spiritual Rudder was not an abstract devotional work, but discussed topics of immediate relevance to early modern sailors. It includes chapters on bankruptcy, payment of servants, the dangers of brandy and tobacco, the discovery of the Americas, the duties of naval officers and many more. Udemans exhorted all who would pursue commercial gains to cherish virtue and a godly reputation before material prosperity. With references ranging from the classical authors like Cicero and Plato, to the Bible and to the most popular political theorists of his day, Udemans made his case 'that Commerce is an honest activity, as long as it is pursued in justice and the fear of the Lord. ${ }^{7}$ Commerce, like all other aspects of life, should be governed by the application of Christian faith. Informed by his books, Udemans took up his pen to write about a topic of public significance and sought to bring about a more Reformed society. In the maritime mercantile province of Zeeland, which was also a bulwark of the Reformed faith, his message was tailored to his local audience.

Udemans' knowledge of sea-faring came from two sources: from the practical knowledge of his congregants who had sailed themselves, and from his books. Udemans' library was auctioned in the year of his death, 1649, with a pre-distributed catalogue to stoke interest amongst book buyers. The catalogue listed many books on economics, politics, war and foreign lands - all topics of use to a well-informed sailor. ${ }^{8}$ Although Udemans' ownership in itself of course does not prove that he actually read the books, it indicates his wide interest in topics other than theology. This essay will show that to read such works was exactly what was expected of minister: it was a minister's duty to apply a Christian perspective on a wide range of subjects of interest to society at large, including trade, politics and science.

If a minister had studied at a university in the Republic, he received a thorough education in all theological topics: biblical studies (including Greek and Hebrew), church history and systematic theology. ${ }^{9}$ But their education did not only prepare them to be theological commentators; universities equipped

7 Udemans, 't Geestelyck roer, f. 4: "dat de Koopmanschap is eene eerlijcke handelinge, als die maer gedreven wordt in de gerechtigheyt, ende vreese des Heeren" All translations are my own unless stated otherwise, italics are mine.

8 All catalogues cited as $A C$ followed by the name of the owner are available at Book Sales Catalogues Online - Book Auctioning in the Dutch Republic, ca. 1500-ca. 180o., advisor: Leiden: Brill, 2015 http://primarysources.brillonline.com/browse/book-sales-catalogues-online. $A C$ Godefridus Udemanns (Middelburg: Jaques Fierens, 1649).

9 For a detailed examination of theological education in the Netherlands during the seventeenth century, see Hendrika Adriana de Bruijn, Eerst de waarheid, dan de vrede: Jacobus Revius 1586-1658 (Zoetermeer: Boekencentrum, 2012), pp. 71-87; H.H. Kuyper, De opleiding tot den dienst des words bij de Gereformeerden (The Hague: Martinus Nijhoff, 1891). 
them to be public intellectuals. In the Netherlands, Dutch ministers were first given an education in a wide variety of topics, often called the arts, that were understood as necessary and preparatory for their theological education. This preparatory study often took two years to complete. A typical course in theology included studies in political theory, jurisprudence, science and medicine, rhetoric, ethics, economics and geography as prerequisites. When they had completed their course of study, aspiring ministers were supposed to be men of letters, or, in the words of an eighteenth-century Dutch minister, 'erudite theologians.' 10

As Udemans' case shows, Dutch ministers addressed Christians' day-to-day cares, and were expected to have a thorough understanding of topics that could be beneficial to their congregations. They understood this as part of a long Christian tradition. In his dedication to the directors of the East and West Indies Companies, Udemans cited the Church Fathers Cassiodorus and John Chrysostom and the medieval scholastic Thomas Aquinas in defence of commerce. ${ }^{11}$ Other Protestant Reformers made a similar case for broad reading. The Zurich Reformer Heinrich Bullinger (1504-1575) reminded readers of his Ratio studiorum that the Apostle Paul and the Church Fathers understood and made use of pagan authors. ${ }^{12}$ Andreas Hyperius (1511-1564), professor of theology at Marburg, encouraged students to understand classical writers, mathematics, science, music, astronomy, economics, history, architecture and even agriculture. ${ }^{13}$ John Calvin himself encouraged Christians to pursue their vocations with diligence and earnestness, because these were expressions of their worship of God. For Calvin, learning from other fields in addition to theology was not only acceptable, it was praiseworthy. 'If the Lord has willed that we be helped in physics, dialectic, mathematics and other like disciplines, by the work and ministry of the ungodly, let us use this assistance. For if we

10 Richard Muller, 'Calling, Character, Piety, and Learning: Paradigms for Theological Education in the Era of Protestant Orthodoxy', in his After Calvin: Studies in the Development of a Theological Tradition (Oxford: Oxford University Press, 2003), p. 118; Jona Willem te Water, De theologo erudito (Leiden: Sam. en Joh. Luchtmans, 179o). Cf. Joris van Eijnatten, 'Theologus Eruditus, Theologus Modestus: The Early Modern Pastor as Communication Worker', in Theo Clemens and Wim Janse (eds.), The Pastor Bonus: Papers read at the British-Dutch Colloquium at Utrecht, 18-21 September 2002 (Leiden: Brill, 2002), pp. 309-318.

11 Udemans, 't Geestelyck roer, ff. $3^{r}-4 \mathrm{v}$.

12 Muller, 'Calling, Character, and Piety', p. 107.

13 Andreas Hyperius, De sacrae scripturae lectione ac meditatione quitidiana, omnibus omnium ordinum hominibus Christianis perquam necessaria, libri II (Basel: Johan Oporinus, 1561), UsTC 631410, pp. 45-80. 
neglect God's gift freely offered in these arts, we ought to suffer just punishment for our sloths.' ${ }^{14}$ Calvin celebrated the ability of these studies to enlighten the Christian mind..$^{15}$

A century later, Dutch ministers and theologians echoed this same message. Gisbertus Voetius (1589-1676), professor of theology at Utrecht, argued that ministers ought to be educated in 'logic, metaphysics, politics, ethics and physics, as a minimum, plus a little knowledge of cosmography and geography'.16 In his oration inaugurating Utrecht's Illustrious School becoming a university in 1636 , Voetius underscored the ways in which knowledge of a broad range of fields would be beneficial to the public good. Theology was the highest discipline because it investigated God, but history, optics, engineering, geography and hydrography were all useful in their own ways. ${ }^{17}$ Guijlelmus Saldenus (1627-1694), a minister in Delft and Voetius' student, argued that portions of the Bible are difficult to understand without prior training in the 'liberal arts:' grammar, rhetoric, dialectic, mathematics, music, geometry and astronomy. ${ }^{18}$ Herman Witsius (1636-1708), a professor of theology who taught at Franeker, Utrecht and Leiden, encouraged young ministers to 'consult in no cursory manner those who are masters in the sciences of logic, grammar, and rhetoric'. He compared learning from the 'school of nature' to the Israelites using the craftsmanship of the Gibeonites, 'whose work was to cleave wood and draw water for use of the sanctuary'.19 Such topics added greater depth to a minister's understanding and aided them in the pursuit of godliness. The expectation was that ministers would understand a wide range of topics beyond the typical theological subjects.

14 John Calvin, Institutes of the Christian Religion, ed. J.T. McNeill, trans. F.L. Battles (2 vols., Philadelphia: Westminster Press, 196o), I, p. 275 (2.2.16).

15 Calvin, Institutes, p. 53 (1.5.2).

16 Gisbertus Voetius, 'Introductio ad Philosophiam Sacram' [Danielo Suavio, 2 July 1651], in his Diatribae de theologia, philologia, historia et philosophia sacra (Utrecht: Simon de Vries, 1668), p. 13 o.

17 Gisbertus Voetius, Sermoen van de Nutticheydt der Academien ende Scholen, mitsgaders der Wetenschappen ende Consten die in de selve gheleert werden (Utrecht: Aegidius and Petrus Roman, 1636) USTC 1029443.

18 Guiljelmus Saldenus, De libris, varioquoe eorum usu et abusu, libri II (Amsterdam: Henricus and Theodore Boom, 1688), p. 202.

19 Herman Witsius, On the Character of a True Theologian (Greenville, SC: Reformed Academic Press, 1994) p. 29. 


\section{Ministers and the Culture of Print}

The library was an important asset for a minister who was expected to be an intellectual authority in his community. Heinrich von Diest (1593-1673), a professor at Harderwijk, wrote De ratione studii theologici necessaria instructio to aid his students in their pursuit of building a library. ${ }^{20}$ In his disputation exhorting ministers to pursue a broad education, Voetius provided a list of books with which an eager trainee could begin. He included over ten theological books and six 'concerning practical philosophy, politics, and jurisprudence'.21 This brief list came from his six-hundred page Exercitia et Bibliotheca Studiosi Theologiae, in which he covered most topics of intellectual investigation and offered a recommended reading list. ${ }^{22}$ Voetius himself owned the largest known ministerial library that sold at auction during the seventeenth century, containing over 5,900 books.

A book was a tool in the culture of persuasion, and Dutch ministers were prolific users. One minister and professor of theology claimed that prior to writing and preaching, he had done the hard work of convincing himself of Scripture's meaning. In his final hours, he reflected 'that I was first persuaded my selfe of the truths of the Gospel which I preached to others.'. ${ }^{23}$ When that minister died, he left a book collection of 4,803 books behind.

Often catalogues of libraries owned by ministers divide the book collections into two broad categories: theology and miscellaneous. The average collection in my dataset that sold at auction was 1,138 books. Several auctions of collections of more than five-thousand books sold. Even if a collection was not large enough to warrant sale at auction, a minister without a library was hardly a minister at all. Church leaders reprimanded those ministers who did not make a concerted effort to develop themselves through books. ${ }^{24}$ The ideal minister was a repository of knowledge, familiar with the biblical text and all other disciplines.

$20 \quad$ Heinrich von Diest, De ratione studii theologici necessari instructio (Harderwijk: Nicolaes van Wieringen, 1634), USTC 1510759 .

21 Voetius, 'Introductio ad Philosophiam Sacram', p. 135.

22 Gisbertus Voetius, Exercitia et Bibliotheca Studiosi Theologiae (Utrecht: Willem Strick, 1644), USTC 1029459.

23 Marie du Moulin, The Last Houers, of the Right Reverend Father in God Andrew Rivet, trans. G.L. (Den Haag: Samuel Brown, 1652), p. 16.

24 G. Groenhuis, De Predikanten: De sociale positie van de gereformeerde predikanten in de Repuliek der Verenigde Nederlanden voor \pm 1700 (Groningen: Wolters-Noordhoff, 1977), p. 165; J. Reitsma and S.D. van Veen (eds.), Acta Der Provinciale en Particuliere Synoden, Gehouden in de Noordelijke nederlanden Gedurende de Jaren 1572-1620 (8 vols., Groningen: J.B. Wolters, 1892-1899), II, p. 147. 
One of the minister's responsibilities was the dissemination of information to his congregation, and, with the advent of the printing press making books far cheaper, that sphere broadened to the literate public. With high rates of lay literacy, Dutch ministers could potentially reach a broad audience beyond their local congregation. ${ }^{25} \mathrm{~A}$ minister at the end of the seventeenth century stated that

God has wonderfully compensated for both the brevity of a minister's life as well as the limited scope of his audience by having given man the wisdom to become acquainted with the art of printing. Now a single minister, even centuries after his death, is capable of preaching to an entire nation, yes, even to the entire world. ${ }^{26}$

Following Luther, Reformed ministers in the Netherlands made direct appeals to reading Christians and sought to persuade them to forsake theological error and ungodly actions. ${ }^{27}$

Indeed, the image of an orthodox minister railing against heresy and error through print is abundantly common, and many of their works were polemical diatribes written to combat the perceived theological error in other ministers' books. ${ }^{28}$ Yet they were not only theologians, and commented on all aspects of life. As a result, ministers devoted themselves to reading about far more than theology. While Bibles, biblical commentaries, theological treatises and devotional works were the bulk of their collections, ministers' libraries would often include dozens, if not hundreds of books on topics that appear to have little to do with religious thought or devotion. Scientific and medical works,

25 On literacy in the Dutch Republic, see S. Hart, 'Enige statistiche gegevens inzake analfabetisme te Amsterdam in de $17 \mathrm{e}$ en 18e Eeuw', Amstelodamum 55 (1968), pp. 3-6; Willem Frijhoff and Marieke Spies, 1650: Hard-Won Unity, trans. Myra Heerspink Scholz (Basingstoke, United Kingdom/Assen, The Netherlands: Palgrave Macmillan/Royal Van Gorcum, 2004), p. 236-237.

26 Wilhelmus à Brakel, The Christian's Reasonable Service, ed. Joel R. Beeke (4 vols., Grand Rapids: Reformation Heritage Books, 1992-1995), I, p. cxiv.

27 Andrew Pettegree, Brand Luther (New York: Penguin Press, 2015).

28 For example, Gisbertus Voetius, Politicae Ecclesiae (4 vols., Amsterdam: Joannis à Waesberge, 1663-1676), Iv, p. 378; Edwin Bezzina, 'The Practice of Ecclesiastical Discipline in the Huguenot Refugee Church of Amsterdam, 1650-1700', in Karen E. Spierling, Erik A. de Boer and R. Ward Holder (eds.), Emancipating Calvin: Culture and Confessional Identity in Francophone Reformed Communities (Leiden: Brill, 2018), p. 171; Frijhoff and Spies, 1650: Hard-Won Unity, p. 266; Noel Malcolm, "The Printing of the "Bear": New Light on the Second Edition of Hobbe's Leviathan', in his Aspects of Hobbes (Oxford: Oxford University Press, 2002), p. 381. 
political theories like Thomas Hobbes's Leviathan, jurisprudence, handbooks on economics, military strategy and even books on agriculture - this diverse range of material regularly featured in ministerial collections. The meagre book collection owned by Thomas Laurentius, a Puttershoek minister, contained 189 books, including fourteen books on medicine. André Rivet owned almost three-hundred of these works, including almost ninety books on political theory, twenty on astronomy and another twenty on science and mathematics. ${ }^{29}$ Bernard Somer in Amsterdam owned a particularly interesting collection of books on military theory, war and fortifications, twenty-three works in total. ${ }^{30}$ Salomon Voltelen in Waspik owned fifteen. Udemans himself owned seven works on jurisprudence. ${ }^{31}$ In their work, ministers offered interpretation and synthesis of such knowledge. They endeavoured to present a cogent, godly picture of the world.

Three genres of non-theological books (medical, economic and astronomical and cosmographical) most clearly indicate the purpose of ministers' reading such a broad range of works. The fields of medicine, economics and astronomy/cosmography had tremendous impact on ordinary life in the seventeenth century Dutch Republic. All three genres focused on aspects that shaped the lives of everyday Dutch citizens, and they were the three topics ministers studied the most, as evidenced by their book collections. The following sections will therefore analyse how ministers used books on medicine, economy and cosmology in their work.

\section{The Minister-Physician}

Illness and disease were a constant concern in early modernity, and this concern required pastoral care. This was especially so since quality medical care was hard to find. While municipal governments would often pay a physician a stipend to offer basic services to the poor, such local practitioners were often untrained surgeons or midwives who depended on medical books like the Secreet-boek by Carolus Battus, which was marketed to readers who only bought a few books. ${ }^{32}$ Battus' prescriptions, based upon humoral theory, are

\footnotetext{
29 Ac André Rivet (Leiden: Pieter Leffen, 1657).

30 Catalogus variorum ac insignium librorum instructissimae bibliothecae Bernardi Someri (Amsterdam: Henricum \& Viduam Theodori Boom, 1685) Wolfenbüttel, HAB: BC Sammelband 9:20.

31 AC Salomon Voltelen (Dordrecht: Wittegaarts, 1697); AC Godefridus Udemans.

32 Carolus Battus, Secreet-boeck waer in vele diversche secreten, ende heerlicke consten in veelderleye verscheyden materien uit Latijnsche, Francoysche, Hoochduytsche, ende
} 
unlikely to have done patients any good. One such prescription encouraged anyone with inflamed ears to use the vapour from sweet milk. Another encouraged rubbing with parsley to ease swelling. As A. Th. van Deursen noted, 'It is quite possible that people found these remedies useful. But their choice and operation rested entirely on faith'. ${ }^{33}$ Works by Battus were listed in six ministerial catalogues.

In total, my database of ministerial libraries lists 1,515 medical books. Fortynine out of the fifty-five minister's collections examined contain at least one medical book. Most ministers would own less than five works on the topic. Of the 343 books a minister in Cuyk owned, only one medical work is listed: De medicina, by the Roman teacher Serenus Sammonicus. ${ }^{34}$ Johannes Boeken, a Lutheran minister in Rotterdam whose collection sold in 1698, owned only Thomas Bartholinus' Anatomia (Den Haag, 1655). ${ }^{35}$ Daniel Demetrius (d. 1628), whose collection sold in 1628, owned two medical books; three sold amongst the collection of Jan Barentsz. (c. 1556-16o9), a minister in Delft. For these ministers, a few books would have served the necessary purpose of providing home remedies without the need for calling a doctor and the ability to inform their congregations at the most basic level.

Thirty-seven ministers, however, owned more than five medical books. The size of these collections ranged from Thomas Laurentius' 189 books, which included fourteen medical books, to collections of nearly six-thousand books. Johannes Pechlinus (d. 169o), a Lutheran minister in Leiden, owned forty-five (his collection totalled 3,709); Jacobus Halsbergius (c.156o-1607) 120, and Balthazar Lydius (1576-1629) even $282 .{ }^{36}$ For these ministers, the desire to own great numbers of medical books indicates an interest in the medical world that surpassed other terrains outside theology. Medical books were far more popular in their collections than scientific works on mathematics, physics, or similar topics.

The medical books that ministers owned tended to be utilitarian in nature, the most popular books being works by Galen and Heurnius (see table 18.1). Many of these books, more than forty percent, was printed before

Nederlantsche authoren, te samen ende by een ghebracht zijn (Dordrecht: Abraham Canin, 160o), USTC 425118.

A. Th. Van Deursen, Plain Lives in a Golden Age: Popular Culture, Religion and Society in seventeenth-century Holland (Cambridge: Cambridge University Press, 1991), p. 238. 1021757 and 1021756; AC Johannes Pechlinus (Leiden: Pieter van der Aa, 169o); AC Johannes Halsbergius (Leiden: Thomas Basson, 1607), USTC 1122231. 
TABLE 18.1 Selection of well-known medical authors in Dutch ministerial book auction catalogues

\begin{tabular}{ll} 
Author & Number of books \\
\hline Galenus & 40 \\
Johannes Heurnius & 31 \\
Daniel Senertius & 27 \\
Hippocrates & 25 \\
Jean François Fernel & 24 \\
Celsus & 19 \\
Johan van Beverwijk & 17 \\
\hline
\end{tabular}

the seventeenth century, making them slightly older than the rest of the collection. The enduring presence of sixteenth-century medical texts is not surprising, as two of the more popular medical authors died before or around 1600: Jean François Fernel died in 1558; Johannes Heurnius died in 16o1. Furthermore, their collections almost exclusively list sixteenth-century editions of Galen, Hippocrates and Celsus.

Why did ministers collect these books? The most compelling reason was to offer care to their sick and dying congregants. Knowing that everyone in their flock would face death, ministers sought to understand the human body in its intricacies, so they could shepherd their flocks through the trials of sickness and dying. The well-known minister Franciscus Ridderus devoted an entire volume to synthesising the best medical books of the day in order to encourage Christians to die well. This work, framed as a dialogue between a minister, a sick man, a doctor and later a widow was entitled Historisch Sterf-huys, ofte 'tsamenspraeck uyt heylige, kerckelijcke en weereltsche historien over allerley voorval ontrent siecken en stervende [Historical Dying House, or a Dialogue from Holy, Ecclesiastical and Secular Histories concerning death and dying $].{ }^{37} \mathrm{In}$ it, Ridderus cited numerous medical authorities, many of whose works were included in the fifteen medical books he owned. ${ }^{38}$ Ridderus' Historical Dying House presents an image of a minister who comforts the sick with Scripture and encouraging spiritual quotations from theologians like John Chrysostom,

37 Franciscus Ridderus, Historisch Sterf-huys, ofte 'tsamenspraeck uyt heylige, kerckelijcke en weereltsche historien over allerley voorval ontrent siecken en stervende (Rotterdam: Johannes Borstius, 1668).

38 Ac Franciscus Ridderus (Rotterdam: Marcus van Rossum, 1683). 


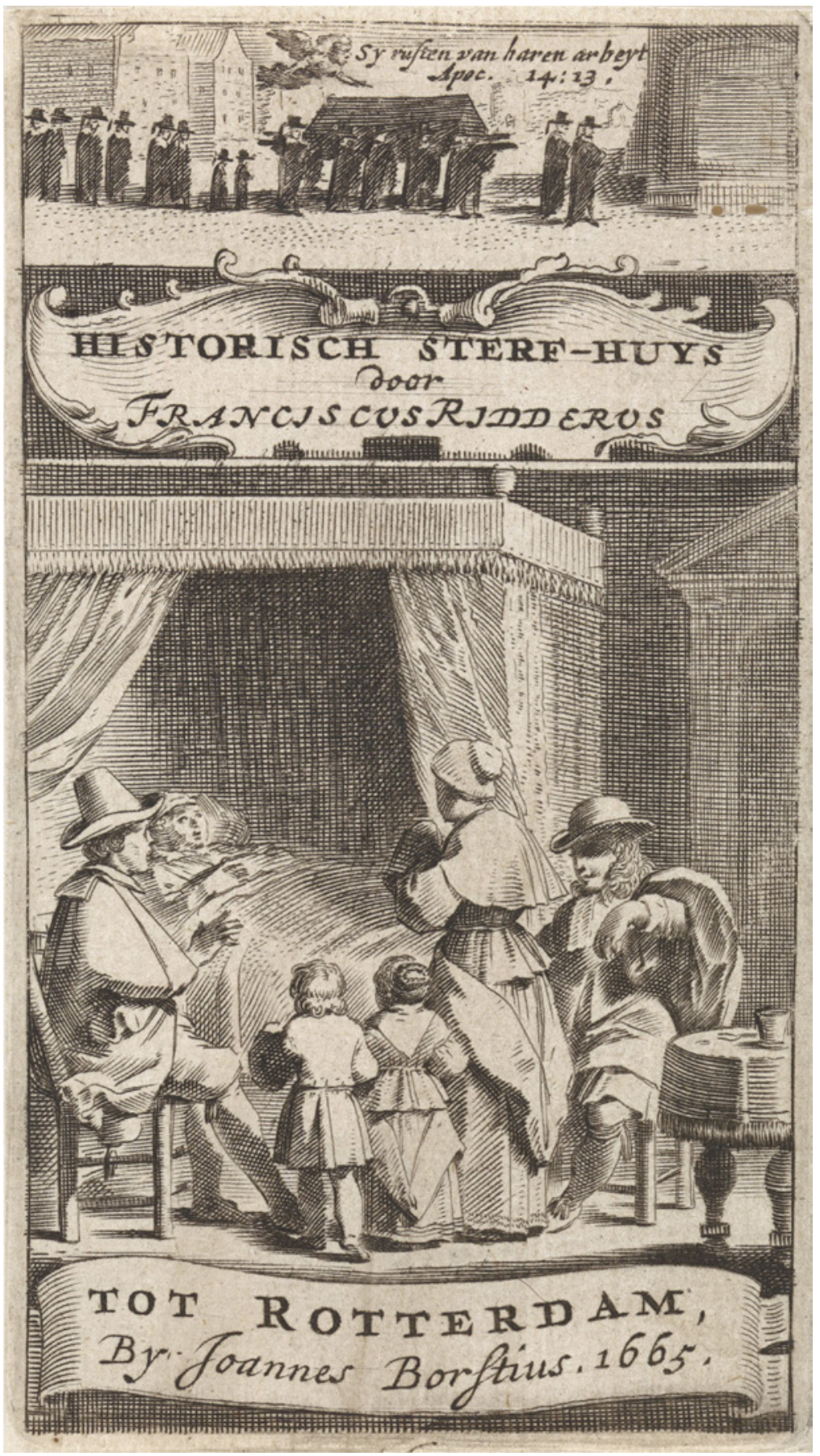

FIGURE 18.1 Pieter Holsteyn, title page of Ridderus' Historisch Sterf-huys, 1665 RIJKSMUSEUM, AMSTERDAM, RP-P-1893-A-18048 
Martin Luther and John Calvin. Yet, in addition to these spiritual guides, Ridderus' ideal minister also understood the advice and treatments given by the doctor and reiterated their advice. He referenced medical doctors of the day, like the influential Dordrecht physician Johan van Beverwijk. In the image on the title page to the 1665 edition, three adults and two children gather around a woman on her death-bed. One person, presumably the minister, appears to offer encouraging words to the dying woman.

The function of medical books appears in other sources as well. In 1670, a newspaper advertised a book on death and dying, claiming that comforters of the sick, ministers, and others would benefit from reading it. The book claimed to be 'useful for those who care for the sick, but also for ministers, theologians, heads of households or all those who sail at sea, or cannot serve formally in church'. ${ }^{39}$ Medical books like these provided them with the necessary background to help the ailing come to terms with their condition.

There were also other ways in which ministers could employ their medical books. Godefridus Udemans was one minister amongst many who devoted time and energy to the physical well-being of his congregation. Udemans' catalogue lists a section of Libri Medici, ten books in total, including the Schat der Gesontheyt [Treasure of Health] by the famous Dordrecht physician Johan van Beverwijck and two works by the renowned physician to the French court, Jean François Fernel. Udemans used this medical knowledge to bolster his moral admonitions. When he denounced dancing as 'the bellows of indecency and instruments of frivolity', Udemans not only expressed his concern for the spiritual well-being of his reader, he also emphasized that dancing had ill effects on the body: 'Medical doctors show us that the violent shaking of the body is dangerous, particularly after a meal. Many dancers come down with pleurisy, blood diseases, or other illnesses because of exhaustion that results from dancing.40 Udemans certainly made selective use of medical research to support his religious aims, but he did not speak from a position of an uninformed, narrow-minded minister. Physicians such as Cornelis Bontekoe discouraged dancing for similar reasons to those mentioned by Udemans. ${ }^{41}$ In

39 'Schat-Boeck der Onderwijsingen voor Kranck-Besoeckers, en Vertroostingen voor Krancken, niet alleen dienstigh voor Siecke-Troosters, maer oock voor Predicanten, Proponenten, Huysvaders, en die geene, die ter Zee varen, of onder 't kruys van aenspraeck niet konnen gedient werden'. Oprechte Haerlemse Saterdaegse Courant 49, 6 December 1670.

40 Godefridus Udemans, The Practice of Faith, Hope, and Love, trans. Annemie Godbehere, ed. Joel R. Beeke (Grand Rapids: Reformation Heritage Books, 2012), p. 365.

41 Anette Henriette Munt, The Impact of Dutch Cartesian Medical Reformers in Early Enlightenment German Culture (1680-1720) (University of London, PhD Thesis, 2004), p. 176 . 
such cases, medical knowledge could come to the aid of their understanding of piety.

\section{They That Bear Silver}

If sickness, dying and medicine were at the forefront of a congregant's mind, economics were a close second. When a Dutch minister considered economics, he was concerned first with the proper order of society. Economics in the early-modern era concerned far more than modern definitions of the field, it was about household management on various scales, foremost the literal family household. For ministers, therefore, economics was a holistic endeavour, of which wealth was only one part. It was the study of order and justice, beginning with the family unit and extending out to the rest of society. Less concern was therefore given to the internal machinations of Amsterdam's Exchange Bank than to the role of virtue in economic dealings.

Economic books were less popular than medical works. Thirty out of the fifty-five catalogues I have transcribed contained books on matters of finance, supply and demand, money, banking or other such concerns. Just over one-hundred of these books are listed in my transcribed corpus. The majority (87) were written in Latin; French and English are the most common vernacular texts present, with five each. Of those books on order, none were more popular than Barthalomaeus Keckermann's volume on politics and economics. Keckermann (c.1572-1608) began his treatise on order with the home. ${ }^{42}$ The peace and concord of society, upon which human prosperity depended, began with a virtuous husband and a wife who showed honour to her husband. According to Keckermann, this familial structure was founded by God, and established the foundation upon which a just economic system was built.

There are two main groups of economics books listed in ministers' auction catalogues: general introductory texts on the household and texts that were topical to controversies on economic issues in the modern sense. Summative books on economics were largely dominated by Aristotle and discussions of his thought. Aristotle's Politica \& Oeconomica is listed five times; there are four books commenting on Aristotle's economics, including two copies of John Case's In Oeconomica Aristotelis. ${ }^{43}$ The most popular economic books, however,

42 Barthalomaeus Keckermann, Synopsis Disciplinae Oeconomicae (Hanau: Wilhelm Antonius, 1610), USTC 2066747. This treatise is appended to his work on politics, Systema Disciplinae Politicae (Hanau: Wilhelm Antonius, 16o8), UstC 2079757. 
mark out a public debate within the Dutch Republic and the Reformed church that spilled into a frenzied controversy. Books on usury, the practice of lending money for profit to the detriment of the recipient of the loan, dominate the genre. Nearly half (47) mention usury in the title. Claudius Salmasius, a professor at Leiden, was the most popular author mentioned in this category. His De modo usuris is listed fourteen times. One of his successors who also wrote on usury, Johannes Friedrich Gronovius was less popular, but well-represented in the corpus. His De centesimus usuris is listed five times.

The controversy over usury had a direct cause. In 1642, Utrecht magistrates asked the theological faculty for advice on the establishment of a lending bank. Citing scripture, civil law and examples from history, the theologians argued vehemently against the practice of loaning money at exorbitant rates. Usury, the theologians stated, 'drank the blood of the poor down to the very marrow' ${ }^{44}$ Such lenders were a cancer and a plague, ruining the city's poor. Publishing numerous tracts in Dutch, Voetius and several colleagues wrote to free the 'poor masses. ${ }^{45} \mathrm{He}$ also composed several academic disputations on the evils of such practice to better train ministers to take up the fight as well. But by taking the debate out of the academy and addressing the people and the government directly through vernacular writing, Voetius sought to usher in a society that had no place for this economical practice.

In taking up usury as a topic of importance to theologians and ministers, Voetius took part in a discussion on usury that went back centuries in the Church. The morality of banking practices such as usury had long been debated in the Christian church. ${ }^{46}$ Usury was an issue on which the first generations of Protestant reformers spoke out. ${ }^{47}$ It was one that consumed much debate during the early modern era, as it was one that affected the lives of many ordinary citizens. ${ }^{48}$ When Voetius denounced abusive banking practices, he had investigated the subject thoroughly. In addition to those instances when usury was discussed in shorter treatments by theologians throughout the Christian tradition, Voetius also investigated the other side of the issue. Of the fifteen or so

44 Quoted in Willem J. van Asselt, “A Grievous Sin:" Gisbertus Voetius (1589-1676) and his anti-Lombard Polemic', in Jordan J. Ballor, et. al. (eds.), Church and School in Early Modern Protestantism: Studies in Honor of Richard A. Muller on the Maturation of a Theological Tradition (Leiden: Brill, 2013), p. 510.

45 Doede Nauta, Samuel Maresius (Amsterdam: H.J. Paris, 1935), p. 297.

46 Charles R. Geisst, Beggar Thy Neighbor: A History of Usury and Debt (Philadelphia: University of Pennsylvania Press, 2013); Juliann Vitullo and Diane Wolfthal (eds.), Money, Morality, and Culture in Late Medieval and Early Modern Europe (Burlington, VT: Ashgate, 2010).

47 Eric Kerridge, Usury, Interest and the Reformation (Aldershot, UK: Ashgate, 2002).

48 Norman Jones, God and the Moneylenders: Usury and Law in Early Modern England (Oxford: Basil Blackwell, 1989). 
books he owned on usury, several actually defended usury, including Samuel Maresius' Conderationes erotematicae circa Foenus Trapeziticum.

Invectives against allegedly greedy, money-grabbing bankers were not only levelled by the orthodox watchdog Gisbertus Voetius and his colleagues in Utrecht. The Synopsis Purioris Theologiae, composed by the Leiden theological faculty after the purge of Remonstrants in 1619, had concluded as much in 1620. 'The lending to the poor for financial gain that is practiced in the form of a pledge, and that is permitted by the magistrates in Christendom to a certain degree because of something good, is clearly cruel and harsh', wrote Antonius Thysius (1565-1640). ' $[\mathrm{A}]$ well-established nation ought to have no place for anyone to practice this. ${ }^{49}$ Jacob Lydius (1610-1679), a minister in Dordrecht, reviled 'money hounds [Gelt-hont]' and all who practiced 'the acts of cunning, dodges, deceits and devilry'. Similar to Udemans, Lydius considered this a failure virtue; it was a 'sin against the old name of honour.'50

Not all ministers fell in line with Voetius. Johannes Cloppenburg (1592-1652), a professor of theology at Harderwijk and later Franeker, was one of the most able opponents of Voetius. He considered usury acceptable within certain parameters. ${ }^{51}$ Such opposition shows that the usury controversy did not split along confessional lines. Cloppenburg's orthodoxy in theological matters was undeniable, while Hugo Grotius, the Arminian who was reviled by Gisbertus Voetius, agreed with the Reformed Voetius on this issue of usury. ${ }^{52}$ The classis of Leiden argued that the Utrecht theologians introduced teachings on usury that were denied by Scripture, the catechism, synodal resolutions and the practice of Reformed churches. They claimed such concerns were not within the purview of the church. Political authorities had the responsibility to establish

49 Antonius Thysius, 'On Almsgiving and Fasting (disp. 37)', in Henk van den Belt (ed.), Riemer A. Faber (trans.), Synopsis Purioris Theologiae/Synopsis of a Purer Theology (2. vols, Leiden: Brill, 2013-2016), II, p. 463.

50 Jacobus Lydius, 'Van eenen gelt-hont', in his Vrolycke Uren, ofte der Wysen Vermaeck (Dordrecht: Hendrick van Esch, 1640), usTC 1017730, p. 10o: "Hier leyt een gierigh mensch, een Gelt-hont in verholen, De doot, gelijck een dief, heeft hem van hier gestolen, en dit gebeurde juyst op d'onbequaemste tijt, soo dat men merken kost 't geschiede maer uyt spijt. Want op de selfde tijt wanneerse hem quam quellen, soo was hy gansch beslet met al syn gelt te tellen, en siet den snooden dief, en fellen moordenaer stal slechts alleen den man, en liet de schatten daer."

51 Johannes Cloppenburg, De Foenore et Usuris, Brevis Institutio, cum ejusdem Epistola Ad Cl. Salmasium (Leiden: Elzevier, 1640). Cf. Neil de Marchi and Paul Harrison, "Trading "in the Wind" and with Guile: The Troublesome Matter of the Short Selling of Shares in Seventeenth-Century Holland', in Neil de Marchi and Mary S. Morgan (eds.), Higgling: Transactors and their Markets in the History of Economics (Durham: Duke University Press, 1994), p. $5^{6}$ (47-65).

52 Henk Nellen, Hugo Grotius: A Lifelong Struggle for Peace in Church and State, 1583-1645, trans. J.C. Grayson (Leiden: Brill, 2014), pp. 514-517. 
what was and was not lawful. ${ }^{53}$ Though the Utrecht theologians and the Leiden classis differed on the policy outcome, both sought the same end: they called for a more Christian society. On 30 March 1658 , the States of Gelderland and Holland settled the political dispute. They concluded with Cloppenburg and the Leiden classis that the church had no authority on these matters. If bankers followed the law, they should not be banned from the Lord's Supper. ${ }^{54}$ Samuel Maresius (1599-1673), a professor of theology at Groningen who defended the practice alongside Cloppenburg and the Leiden classis, revelled in the fact that his position had won the day in both the ecclesiastical and political fields. ${ }^{55}$

Through common-sense observation, knowledge of the Bible and the occasional reading of books on economics, ministers in the Republic exhorted congregants and those in secular authority to pursue a Reformed agenda in economic matters. Ministers encouraged virtue above wealth, honour rather than glory, and humility and circumspection in place of earthly status. Armed with the knowledge of their opponents' best arguments for and against usury, ministers constructed their responses. They employed the pen to persuade readers - whether ordinary citizens, local magistrates, or provincial or national authorities - of the error of allowing such sinful banking practices to exist. Ministers voiced their opinions so vociferously on economic matters that the political authorities had to step in to settle the dispute and maintain concord. Print elevated a minister's voice and intellectual authority beyond his local church and amplified it beyond the walls of their local church: all in the hope of establishing economic policy.

\section{Reading the Stars}

Questions of sickness, death and obtaining one's daily bread were unavoidable. Every person would have been acutely aware of their frailty; and many were especially aware of the need to earn more money. These were daily, even hourly concerns. Some events, though, captured national attention in sudden, unexpected moments. When a comet soared through the sky on a winter's night in 1664, men, women and children stood in awe. It was one of many observed in the seventeenth century. Astronomical events like comets, beached whales

'Aensprack tot den Christelijcken Leser', Res judicanda, Saecke die noch state te oordeelen, van de bancken van leeninghe, by de magistrate opgerecht (Leiden: Hendrick Verbiest, 1658), pp. 8-9.

54 Van Asselt, “A Grievous Sin:" Gisbertus Voetius (1589-1676) and his anti-Lombard Polemic', p. 519.

55 Nauta, Samuel Maresius, p. 297. 
and other natural phenomenons became shared cultural experiences that led to broad social discussion. They were cultural events that captured the public imagination for a time. ${ }^{56} \mathrm{~A}$ surge of pamphlets sought to explain what such heavenly spectacles meant: how and why the comet emerged.

Ministers jumped into the fray. Many Dutch pastors thought that the comet was a sign from God himself, warning the wayward nation to turn from sin and godlessness and return to faithful Reformed belief and action. Gisbertus Voetius suggested as much. A comet was an ominous sign, sent by God, that ought to stir up reverence towards Him. ${ }^{57}$ What the comet might have signified was not expressly clear, Voetius thought, but 'from the experience of all times and the verdict of all men, they do announce drastic changes'.58 Such explanations were common amongst observers before and after Voetius. Yet Voetius was not wholly ignorant of the scientific findings taking place around him. When the irascible theologian's book collection sold in 1676 and 1679 , forty-eight books on astronomy sold. Throughout his life, Voetius read books seeking to explain the celestial realm and, in concert with Scripture, he came to a reasoned conclusion.

Including cosmographical books (of which there are almost sixty), 693 books describing the planets and stars are listed in my database of fifty-five ministerial catalogues $(0,77 \%)$. Of those fifty-five ministerial catalogues transcribed thus far, they list an average of just over ten works on the topic. This figure is skewed, because a few collections contained an outlying number. Some collections contained about an average, if slightly more. Jacob Arminius owned sixteen, including two copies of the medieval monk and astronomer Johannes de Sacrobosco's De Sphaera Mundi. ${ }^{59}$ A few owned far more than average. Johannes Pechlinus, a Lutheran minister in Leiden, owned thirty-nine. ${ }^{60}$ Abraham Heidanus, a minister and later professor at Leiden, owned fifty-one, including Galileo's Systema Mundi. ${ }^{61}$ Justinus van Assche owned over seventy. ${ }^{62}$

56 Andrew Fix, 'Comets in the Early Dutch Enlightenment', in Wiep van Bunge (ed.), The Early Enlightenment in the Dutch Republic, 1650-1750 (Leiden: Brill, 2003), pp. 157-172; Eileen Reeves, Evening News: Optics, Astronomy, and Journalism in Early Modern Europe (Philadelphia: University of Pennsylvania Press, 2014); C. Doris Hellman, The Comet of 1577: Its Place in the History of Astronomy (New York: AMs Press, 1944).

57 Gisbertus Voetius, Selectae Disputationes Theologicae (5 vols., Utrecht: Joannis à Wansberge 1649-1669), II, p. 912.

58 Voetius, Selectae Disputationes Theologicae, II, p. 929.

59 Ac Jacob Arminius (Leiden: Thomas Basson, 1610), UstC 1506632.

6o Ac Johannes Pechlinus (Leiden: Pieter van der Aa, 169o).

61 Ac Abraham Heidanus (Leiden: Felix Lopez de Haro \& widow and heirs Adrianus Severinus, 1679).

62 Ac Justinus van Assche (Rotterdam: Simon Simonsz Visser, 165o), USTC 1121734. 
Some ministers went far further in pursuing knowledge of the heavens above than only reading about them. Jacob du Bois, a minister in Leiden, sought such information beyond books. He wanted to become acquainted with the scientific practice himself. An author on Cartesianism and a chronology of world history from creation to Jesus' crucifixion, Du Bois had Samuel Karl Kechel, the curator for astronomical instruments at Leiden University, tutor him in the field. ${ }^{63}$

Astronomical and cosmographical books largely fell into three categories: classical and medieval, modern, and polemical. As a group, classical and medieval authors were the most popular in the genre. Marcus Manilius, a Roman author, had ten works listed; Ptolemy and Proclus, seven. Gaius Julius Solinus, a third-century Latin grammarian and map-maker, was similarly popular, with ten books on the description of the world. Amongst those sixteenthand seventeenth-century authors, none were as popular as Philip Lansbergius, Johannes Kepler and Sebastian Münster. Münster's popularity can be traced, in part, to the utility of his work. The Cosmographia served as an indispensable proto-encyclopaedia that sought to describe the history and description of the world. In a single folio volume, it 'created a universal geography, and joined to it a history which brought all the empires of man into a meaningful progression' ${ }^{64}$ Tycho Brahe, the famous Danish astronomer whom Ridderus cited, is conspicuously absent from the most popular authors. Only five of his works are listed.

TABLE 18.2 The six most popular authors of astronomical and cosmographical works in ministerial book auction catalogues

Author Number of books

$\begin{array}{ll}\text { Philip Lansbergius } & 20 \\ \text { Johannes Kepler } & 18 \\ \text { Sebastian Münster } & 17 \\ \text { Dionysius Alexandrinus } & 16 \\ \text { Paulus Merula } & 12 \\ \text { Johannes de Sacrobosco } & 12\end{array}$

63 Preface to Jacob du Bois, Oude-tyds tyd-thresoor ende kerkelikke historie (Leiden: Cornelis Banheining, 1650), USTC 1023031.

64 Matthew McLean, The Cosmographia of Sebastian Münster: Describing the world in the Reformation (Aldershot: Ashgate, 2007), p. 341. 
TABLE 18.3 Selection of well-known and celebrated astronomical authors in fifty-five Dutch ministerial book auction catalogues

Author

Number of books

George Purbachius

10

Galileo Galilei

9

Christopher Clavius

8

Nicolaus Copernicus

8

Ptolemy

One of the most popular authors present in the corpus indicates the purpose of astronomical studies for many of these ministers: Philip Lansbergius (Philips Lansbergen), whose various works were listed twenty times. Knowledge of non-theological fields varied greatly amongst ministers. Some were content with the knowledge gleaned from experience and those Christian theologians who addressed such topics in their writings; others, however, pursued knowledge beyond religious studies with as much drive and determination as they did for their pastoral care, few more so than Philips Lansbergen. Unfortunately, either a catalogue for his collection was never composed or it has not survived.

Born in Ghent in 1561, Lansbergen and his family were part of the exodus of Reformed believers to the Northern Netherlands after the fall of Antwerp in 1585. Lansbergen's interest in astronomy was likely kindled while he was a young man in the Southern Low Countries. His first publication on the topic came in 1588, only two years after he departed Leiden to become a minister in Goes. As a fierce proponent of Reformed theology, he was relieved of his pulpit after he chastised the magistrates for their forbearance towards suspected Roman Catholics. In 1613, he moved to Middelburg and dedicated the rest of his life to propagating a Copernican view of the universe that affirmed the authority of the Bible. It was a distinctly 'Christian cosmology'.65 In 1629, he defended the orthodoxy of his position, stating that his Bedenckingen op den Dagelyckschen ende Jaerlyckschen loop van den Aerdt-Cloot, Mitsgaeders op de ware af-beeldinghe des sienlijcken Hemels [Considerations on the Daily and the Yearly Course of the Terrestrial Globe, and on the True Depiction of the Visible $S k y]$ was, "built not only upon the foundations of geometry, but also upon the

65 Rienk Vermij, The Calvinist Copernicans: The reception of the new astronomy in the Dutch Republic, 1575-1750 (Amsterdam: Koninklijke Nederlandse Akademie van Wetenschappen, 2002), p. 88. 
testimonies of the Word of God. Both of which are so infallible, that one cannot doubt its certainty and truth' ${ }^{66}$ For Lansbergen and many other ministers, understanding the physical world was an exercise in piety.

Lansbergen undertook the pursuit of astronomical knowledge for pious ends further than practically any other minister at the time. And yet, he is not wholly distinct from other ministers at the time. The difference between Lansbergen's study of astronomy and many other ministers' is in degree, not kind. Other ministers, too, sought to comprehend how God established creation, including the rotation of the stars. Lansbergen simply went further in his study. Lansbergen sought to use his knowledge of astronomy for the spiritual benefit of his fellow Reformed believers in the Netherlands.

Franciscus Ridderus in Rotterdam published a tract in 1665 entitled Reysdiscours op het verschijnen van de comeet-sterre, die voor d'eerstemael gesien is den 15 december des jaers 1664 [A travel dialogue on the appearance of the Comet, which was first seen on 15 December in the year 1664$].{ }^{67}$ In this discourse between a student, a citizen and a traveller, the student summarized the new science, which claimed the comet was a natural phenomenon with no spiritual meaning. The traveller rebukes him and offers the definitive explanation on the meaning of the comet's appearance. He argues three points: a scientific explanation is inadequate for comprehensive understanding of the comets full meaning, predictive astrology is to be condemned, and (like Voetius) it is a sign of Divine hostility. Ridderus grounds the traveller's expertise not only in Scripture, but in his own expertise gained through investigating books. He attempts to overwhelm any dissenting view with philosophical, historical, theological and scientific references. He cites works by classical authors such as Seneca and Aristotle, but also contemporary scientific theorists like Bartholomaeus Keckermann and even 'the learned Star Gazer', Tycho Brahe. ${ }^{68}$ The traveller's position is confirmed by a combination of Biblical proof and scientific observation. Ridderus, who has cast himself as this learned traveller, explained his process of information gathering. 'I desired to investigate some

66 'Want gelijck de gronden vande Meet-const, geheel vast ende seker zijn, alsoo zijn oock de getuygenissen van Gods woort, 't eenemael waerachtich, jae de waerheyt selve'. Philips Lansbergen, Bedenckingen op den Dagelyckschen ende Jaerlyckschen loop van den Aerdt-Cloot, Mitsgaeders op de ware af-beeldinghe des sienlijcken Hemels (Middelburg: Zacharias Roman, 1629), uSTC 102673o, f. *3r.

67 Franciscus Ridderus, Reys-Discours op het verschijnen van de Comeet-sterre, die voor d'eerstemael gesien is den 15 december des jaers 1664 (Rotterdam: Henricus Goddaeus, 1665).

68 'De gheleerde Sterre-kijcker Tycho Brahe'. Ridderus, Reys-Discours, p. 15. 
authors and, then to summarize their conclusions'. ${ }^{69}$ Ridderus underwent the difficult process of collecting sources, internalizing and understanding them, and presenting a biblically informed view of a topic that would have gripped his congregants' attention.

Ministers often differed on the importance of astronomy to the Christian faith. In 1608 Sibrandus Lubbertus, a professor of theology at Franeker who was happy to combat those teachings he found heretical, suggested Copernicanism was merely an astronomical hypothesis. It was simply a scientific theory that had little to no bearing on the theological matters. ${ }^{70}$ The auction catalogue composed to advertise the sale of his library does not list any works by the famed Danish astronomer.

Astronomical events provoked heated debate in the academy and the church alike. ${ }^{71}$ Lansbergen's reference to both geometry and the Bible hints at the debate that would erupt not long after his death. Was the sun or the Earth the centre of the universe? Du Bois' preoccupation with learning first-hand how astronomy was practiced only makes sense if much more was at stake than a scientific theory about whether the Sun of the Earth was the centre of the universe. The question was a proxy war, many thought, for a debate about the authority of the Bible, because as they understood it, the Bible suggested the Earth stood still. Ministers and professors (in addition to astronomers and mathematicians) were some of the most vocal pundits on the events.

Debates in obscure corners of the theological world could reach the heart of nations if pursued with enough vitriol. Up and coming ministers tried to advance their position in the Dutch Reformed church by inserting themselves in these discourses. At only twenty-five years old, Petrus van Mastricht (16301706), a minister in Xanten (a village near Duisberg) wrote Vindiciae veritatis et autoritatis sacrae scripturae against the published dissertations of the newly hired professor of theology at Duisburg, Christophor Wittichus (1625-1687). Wittichus argued that Cartesianism and its heliocentric view of the world were in full accord with the Bible's teaching. ${ }^{72}$ In $165^{2}$, two professors at the Duisburg University, in the Duchy of Cleves, became embroiled in a controversy about Cartesianism when Cyriacus Lenz. Wittichus, the professor of theology at Duisburg, gave two disputations defending the new philosophy.

69 'Soo dreef mij de lust om eenighe autheuren near te sien, den dese Regaltjes uyt haer soo kortelijck bij een te stellen'. Ridderus, Reys-Discours, f. A2r.

$70 \quad$ Vermij, The Calvinist Copernicans, p. 247.

71 Vermij, The Calvinist Copernicans; Eric Jorink, Reading the Book of Nature in the Dutch Golden Age, 1575-1715 (Leiden: Brill, 2010).

72 Petrus van Mastricht, Vindiciaeveritatis et autoritatis sacraescripturae in rebus Philosophicis adversus dissertations D. Christophori Wittichii (Utrecht: Johannes à Waesburge, 1655). 
The second supported Descartes theory on the motion of the Earth, in opposition to the standard Reformed view that the Earth stood still. The brouhaha that erupted after the disputation was such that it was republished in 1655 , in Amsterdam. ${ }^{73}$

Naturalistic explanation of phenomenons like the 1664 comet were suspect because they failed to capture the wonder of God's operation in the world. Ministers claimed the Bible taught that such events were supernatural in cause. Godefridus Udemans was convinced Christians should examine the heavens and marvel at their Creator - and not at the heavens themselves.

Scripture clearly warns us against astrology, which is predicting one's fortune or misfortune from the stars.... We do not ban astronomy and the study of the course of the heavens, as long as man stays within the confines of nature and Scripture, and does not bind God's wisdom and power to it, but instead is moved to praise God the way the holy patriarchs and prophets did. ${ }^{74}$

When critics within the Reformed Church like Wittichius began siding with René Descartes on philosophical and scientific matters, ministers like Van Mastricht and Du Bois recognized it as an attack against Scripture. To bolster the faith of those Christians who might be carried along by the eloquence of such teaching, they took to print. When ordinary church members gazed into the awesome expanse above them, ministers wanted to be sure the sight encouraged their faith, as that was the purpose of the heavens in the first place. 'The heavens declare the glory of God; the skies above, his handiwork' (Psalm 19:1).

\section{Conclusion}

The ministry was a reading profession. With their book collections, ministers studied matters of public importance and offered their perspective through print. Devoting themselves to a lifetime of reading, ministers attempted to bolster their knowledge of the faith and its implications for daily life. Having learned, they then preached and wrote to bring about a more Reformed society.

73 Theo Verbeek, Descartes and the Dutch: Early Reactions to Cartesian Philosophy, 1637-1650 (Carbondale, Ill.: Southern Illinois University Press, 1992), p. 74.

74 Godefridus Udemans, The Practice of Faith, Hope, and Love, trans. Annemie Godbehere, ed. Joel R. Beeke (Grand Rapids: Reformation Heritage Books, 2012), p. 212. 
As Herman Witsius stated, 'For it is when he goes forth from the sacred mount of contemplation, his soul manifestly replenished and radiant with the purest light, that he is best fitted to communicate that light of reflection to others.' ${ }^{75}$

The Reformed faith presented a framework for understanding every aspect of creation. The divide between theology and natural sciences was largely non-existent in the seventeenth-century. Science and economics were not completely distinct from theology and morality. Ministers understood themselves not only as ambassadors for a set of religious convictions, but as the public intellectuals who were charged with helping their flocks understand every aspect of their daily lives from a Reformed point of view. After years of dedicated study, acquiring hundreds and often thousands of books, the ideal minister presented an informed case to live Christianly as a banker, merchant, sailor, weaver, mother or father. Even when petitioning the States failed to bring about the stricter Sabbath observation, virtuous lending practices, or to eradicate certain pernicious ideas from the public square, ministers attempted to persuade their congregations. The ideal theologian built a library that contained a diverse range of books as an aid in their struggle for a Reformed society.

75 Witsius, On the Character of a True Theologian, p. 38. 